\title{
Embodied values: post-pharmaceutical health and the accumulation of surplus vitality in regenerative stem cell medicine
}

\section{Christian Haddad* (1)}

\begin{abstract}
This paper analyzes an emerging form of post-pharmaceutical health and its underlying regime of value in the global bioeconomy of regenerative stem cell-based medicine (RSCM). Animated by a vision to overcome drug-based therapies and their underlying political economies, RSCM pursues a form of regenerative health that is strikingly at odds with pharmaceutical regimes of drug research, regulation and therapy. To offer a theoretical account of these competing forms of health, the paper provides an analysis of the regimes of values that underpin pharmaceutical and regenerative health respectively. This analysis is done alongside three dimensions: the interlinkage between knowledge, technology and economic value creation; its relation to normative values and ethics; and conceptions and valuations of the biomedical subject and his/her body in biomedical research, intervention and innovation. Contrasting these two diverging regimes of health and value suggests that in RSCM the pharmaceutical logic of accumulating "surplus health" is not entirely dismissed but re-articulated in a regime based on the (re-)generation of regenerative biovalue through the extraction and ex vivo accumulation of "surplus vitality". Finally, the article discusses "post-pharmaceutical health" as a sensitizing concept that offers new research avenues into emergent forms of health, value, and subjectivity beyond RSCM.
\end{abstract}

Keywords: Bioeconomy, Biovalue, Health regimes, Pharmaceuticals, Regenerative stem cell medicine, Regulatory pharmaceuticalization.

* Austrian Institute for International Affairs, Vienna, Austria. 


\section{Valores incorporados: salud post-farmacéutica y la acumulación de vitalidad excedente en la medicina de células madre regenerativas}

\section{Resumen}

Este artículo analiza una forma emergente de salud post-farmacéutica y su régimen subyacente de valor en la bioeconomía global de la medicina regenerativa basada en células madre (MRCM). Animada por una visión de superación de las terapias basadas en medicamentos y sus economías políticas subyacentes, la MRCM persigue una forma de salud regenerativa que está marcadamente en desacuerdo con los regímenes farmacéuticos de investigación, regulación y terapia de medicamentos. Para ofrecer una explicación teórica de estas formas de salud en competencia, el artículo proporciona un análisis de los regímenes de valor que sustentan la salud farmacéutica y la regenerativa, respectivamente. Este análisis se hace según tres dimensiones: la interconexión entre el conocimiento, la tecnología y la creación de valor económico; su relación con los valores normativos y la ética; y las concepciones y valoraciones del sujeto biomédico y su cuerpo en la investigación, intervención e innovación biomédicas. El contraste de estos dos regímenes divergentes de salud y valor sugiere que en la MRCM la lógica farmacéutica de acumular "salud excedente" no se descarta completamente, sino que se rearticula en un régimen basado en la (re)generación de biovalor regenerativo a través de la extracción y la acumulación ex vivo de "vitalidad excedente". Finalmente, el artículo analiza la "salud postfarmacéutica" como un concepto instigador que ofrece nuevas vías de investigación en formas emergentes de salud, valor y subjetividad más allá de la MRCM.

Palabras clave: Bioeconomía, Biovalor, Regímenes de salud, Medicamentos, Medicina regenerativa de células madre, Farmacologización reguladora. 


\section{Introduction}

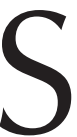

ince the turn of the millennium, stem cell therapies have been central to an innovative biomedical paradigm, so-called "regenerative medicine" (Webster, 2013). This regenerative stem cell-based medicine (RSCM) promises a new approach to disease research and treatment, especially for currently incurable diseases and for those for which pharmacological approaches fail to deliver effective therapies. But beyond promises to expand the spectrum of treatable medical conditions per se, RSCM casts a vision of a revolutionary new type of medicine based on actual regeneration, that is, on healing, rather than on mere symptom treatment. This post-pharmaceutical vision is further tied to a whole range of innovation promises such as the creation of novel industries and markets, the overhaul of dilapidated health systems, the enhancement of national competitiveness in a global knowledgebased economy - or even culminating in the idea to reduce the individual and social pressure of aging, nourishing on the mythological fantasy of finally being able to defeat death (Cooper, 2008; Gottweis et al., 2009).

High hopes and expectations on the side of all involved - patients, investors and policy makers, as well as biomedical communities and biotech firms betting on the speculative clinical and commercial value of RSCM - have created a veritable pressure to perform and bring stem cell-based therapies to clinic and market as rapidly as possible (Morrison, 2012). In a veritable "rush to the clinic" (Wilson, 2009) that has taken shape on a global scale, various clinical and corporate actors have sought to realize the promise of RSCM and deliver actual stem cell-based therapies to patients in need (Salter et al., 2015; Rosemann et al., 2016; Bharadwaj, 2018). Yet, not only have expectable challenges to the clinical translation process curbed hopes for rapid clinical uptake (REFs); strikingly divergent visions of what desirable and responsible innovation pathways for regenerative stem cell-based therapies are in the first place have also sparked substantive conflicts within and beyond biomedical communities (Haddad et al., 2013; Rosemann; Chaisinthrop, 2016). 
Whereas large parts of Western biomedical communities promote innovation pathways that follow, by and large, the "pharmaceutical pipeline" model of research, development and commercialization (ISSCR, 2018a), others have explored entirely different medical innovation approaches for stem cell-based therapies (Bharadwaj, 2014). All over the world, a plethora of stem cell therapy centers have emerged that offer treatments considered experimental - both in terms of their unproven developmental character as therapies and in terms of the tinkering with broader sociotechnical, legal and commercial models of biomedical innovation. Alarmed by the surge of these experimental practices, regulators and professional societies have sought to control the unregulated treatment market, often by trying to discipline "rogue" clinics and to re-inscribe experimental stem cell-based therapies into the regulatory regimes of pharmaceutical research and development. However, the numerous attempts to suppress both the supply and the demand for experimental stem cell treatments have remained largely unsuccessful globally (Sipp et al., 2017).

Against this background of the spread of these unruly practices, diverse forms of active resistance against this "regulatory pharmaceuticalization" (cf. Faulkner, 2012) of RSCM have taken shape. Whereas many stem cell therapy companies have just tried to dodge the regulatory actions through diverse tactics, other clinics and companies have taken up the battle to defend, in public debates or court trials, their vision of innovation in RSCM against what is seen as the stifling incorporation of stem cells into the pharmaceutical-regulatory complex (Tersal, 2012).

In other instances, patients have spoken up publicly, signed petitions and protested in the streets in order to halt what is denounced as a "pharmaceutical seizure" of bodies and cells (Abbott, 2013; PR Newswire, 2013). Soon, a range of powerful think tanks, academics and politicians (all perhaps for their own reasons) have started to support the cause and have criticized the apparent reluctance of established biomedical and regulatory institutions to adequately respond to changing needs and challenges pertaining to emerging innovative technologies. Moreover, proponents of 
such "alternative" approaches to stem cell development started to organize and establish professional networks and institutions in an effort to normalize non-pharmaceutical innovation models in RSCM (Rosemann; Chaisinthrop, 2016). As a result, past years have seen the emergence of some parallel universe of alternative institutions that develop and propagate competing standards for quality control, ethical assessments, and systems of accreditation for regenerative stem cell-based medicine (Blasimme, 2013, Rosemann; Chaisinthrop, 2016).

\section{Towards a post-pharmaceutical form of health?}

The initial proposition of this contribution is that what appears from the vantage point of Western biomedicine as "deviant" practices or crude anti-pharmaceutical sentiments within misguided or ignorant parts of RSCM communities does not simply represent some sort of teething problem of a nascent field of biomedicine. Rather, conceptualizing these seemingly "anti-pharmaceutical" contestations in terms of articulations of an emerging post-pharmaceutical regime of health helps us to discern broader problematizations of health, value and subjectivity at the onset of the 21 st century.

From this conceptual perspective, RSCM is a salient site of biopolitical articulation and experimentation for an emerging global bioeconomy of the life sciences, in which the nexus between health and biomedicine is being reimagined and reconfigured. The central thesis of this article is that in RSCM not only innovative products and possibly better therapies are being developed, but that also the meaning of health itself is at stake - that is, how health is conceptualized and rendered intelligible as an object of knowledge, how it ought to be produced, promoted, valued, commodified, delivered, and consumed as a good, and who the subjects are in these processes.

On these grounds, this article offers a theoretical account of emerging post-pharmaceutical health regimes by analyzing the nexus between health and value in RSCM and contrasting it with that of pharmaceutical regimes. 
While the research that supports my argument is based on empirical case study research, which formed a part of my Ph.D. project (Haddad, 2016), the thrust of this article is essentially theoretical. Its focus is on how health and value CO-constitute mutually in RSCM, and how this regime differs from the pharmaceutical regime of health and value it professes to supersede. To do so, I compare and contrast the two respective health regimes pharmaceutical and regenerative - in an ideal-typical manner.

The article proceeds as follows: In the next section, I draw on two case vignettes to illustrate and better contextualize the political contestations over the regulatory pharmaceuticalization of RSCM. Yet, the scope of the problem runs deeper than these political-phenomenological explorations of anti-pharmaceutical articulations might suggest and concern the very network of relationships between power, knowledge, subjectivity, and value that constitute and underpin health regimes. Therefore, the third section develops the theoretical framework and key concepts that guide the analysis of health regimes: health, value, knowledge, and subjectivity. Based upon these elaborations, the main analytical part of this paper carries out a theoretical and comparative analysis of pharmaceutical and regenerative health. Put in contrast, it is possible to discern substantive differences in the ways health and value are generated and accumulated in pharmaceutical and regenerative medicine. Whereas pharmaceutical regimes depend on the incessant growth of "surplus health" through the expansion of drug intake on an individual and population level, regenerative medicine strives to growth "surplus vitality" by maximizing the extraction and ex vivo preservation of somatic stem cells. 


\section{Contesting the regulatory pharmaceuticalization of stem cell therapies}

The clinical and commercial practices of experimental RSCM are at least as diverse as the forms of problematization, contestation, and resistance to regulation that have taken shape globally. While it is thus impossible to present any "exemplary" case, the small vignettes presented next are indicative for a particular type of political articulation that problematizes the relationships between patients, their bodies, and their own bodily stem cells in an expressively anti-pharmaceutical discourse.

\section{Anti-pharmaceutical articulations}

Around 2008, a private Colorado-based orthopedic clinic developed an innovative treatment based on the patient's own bodily stem cells and started to market its treatment to patients (Cyranoski, 2012). The thrust of the clinic's promissory vision was not only to provide effective treatments for chronic knee and back pain, but also to revolutionize orthopedics altogether by advancing less invasive regenerative approaches "beyond pills and scalpels". These practices, however, led to a conflict with the US Food and Drug Administration (FDA). The FDA reasoned that such bodily stem cell therapies are analogous to drugs and should be regulated accordingly. For this reason, the clinic's activities arguably corresponded to a process of manufacturing and marketing of drugs for which it had neither the required marketing authorization nor the approval for clinical trials.

The clinic, in turn, argued that its approach was not about product development, but consists in an innovative procedure, which has greater similarities with genuinely medical practice fields - such as blood donation, artificial insemination, or organ transplantation - than with industrial drug production. Accordingly, the application of patient-own stem cell therapies falls within medical authority, which is explicitly protected from access by drug regulatory agencies. FDA's competence, which is democratically legitimized by the US Congress, is indeed limited to control, in the name of 
public health and consumer protection, the quality and safety of consumer goods sold in the pharmaceutical marketplace, but not the way medicines are prescribed and used by medical professionals in the clinic (Berry, 1997).

As the controversy worsened, the clinic carried the dispute to court. Its medical director responded and stressed militantly that the trial will settle the dispute once and for all:

[The] courts will decide if the FDA has regulatory authority over the adult stem cells that live in everyone's body [...] [and whether] the government has the right to restrict a patient and their doctor from using a person's own stem cells to treat disease. [We] believe that stem cells are body parts and not the property of the government or big pharma (PR Newswire, 2010, emphasis added).

Large parts of the media have picked up this David vs. Goliath narrative, stylizing the litigation as a showdown between the mighty drug regulator and a small clinic, which will set the future course and direction for regenerative medicine.

In this context, the advocacy group Patients for Stem Cells launched an online petition to support the cause, titled "Stop FDA shutting down adult stem cell research" (Tersal, 2012). Under the slogan of "My Body $\neq$ Drug!", the petition read as a manifesto against the pharmaceuticalregulatory complex. Criticism was directed primarily against the FDA, which was framed as an aggressive agency that arguably had expanded its competence to the area of medical practice by trying to inscribe stem cell therapies into the legal framework for pharmaceutical research and its political economy of regulated drug markets. By using this argumentation, in turn, the agency could extend its authority not only to a new substance class, but rather to the entire field of medical practice:

This classification of a person's stem cells as a "drug" means the government is not only interfering in scientifically proven medical care but also they claim to have jurisdiction over your own body's cells. This has wide implications of control of medicine and the loss of the individual's rights to choose the medicine of their own preference. The extraction and re-injection of adult 
stem cells is not medically different from an in vitro fertilization conducted outside the body (Tersal, 2012).

A similar controversy occurred in Italy over Stamina Foundation, a provider of experimental therapies particularly for pediatric conditions (Abott, 2013). When authorities wanted to stop the experimental treatments due to pressure from concerned health professionals, there were massive protests. Patients and their families demanded a "right to treatment" and medical self-determination in the context of serious illness. "Il corpore è mio! - It is my body!" was the tenor of the protests against an allegedly illegitimate state intervention in the privacy of the body, personal autonomy, and the doctor-patient relationship. Simultaneously, images of children's coffins taken through many major Italian cities, of women who staged their naked bodies in the activist protest style of the women's rights organization Femen, as well as of people in wheelchairs who were angry about medical-state paternalism, were broadcasted by various media channels worldwide. In the wake of the protests, Italian courts temporarily lifted the regulatory action against Stamina and ordered a large, publicly funded study to be conducted to verify the efficacy - and thus legitimacy - of these treatment offers.

\section{Beyond drug access activism and anti-pharmaceutical sentiments}

If mirrored against the experiences of (mostly Western) patients' activism and "right to access" movements (see e.g. Epstein, 1996), these confrontations over bodies, rights, and medicines might appear familiar. However, we also find crucial differences that reach beyond the pharmaceutical form of struggles over drug research, regulation, and access.

To begin with, there is the trade-off between innovation and regulation. Time and again, deregulation advocates have criticized that the institutions that intend to protect the health and safety of patients are in fact doing them harm through too much regulation. While the criticism voiced in the cases discussed here somewhat seems to reiterate this line of reasoning, it actually runs much deeper. Far from lamenting a state of excessive regulation, 
the very authority of drug regulatory agencies as such is challenged as both politically illegitimate and scientifically inappropriate for RSCM innovation.

Secondly, this challenge to drug regulatory regimes further resembles the many instances where patients were fighting for access to experimental treatments. From the 1980s onwards, participation in clinical trials was redefined as a social good that was vociferously demanded, for example by HIV/AIDS patients in the face of terminal, life-threatening illness (Epstein, 1996). More recently, cancer patient groups have even gone a step farther and have demanded a constitutional right to obtain investigational drugs that are in mid and late stage clinical development, even if there is only the smallest chance that the drugs might benefit terminal patients (Annas, 2007). And yet, the contestations over RSCM fundamentally go beyond this logic of exception. First and foremost, as in the case of the Colorado-based clinic, the medical conditions where stem cell therapies are deemed desirable treatments do not have to be considered terminal. The promissory vision of a regenerative medicine, as discussed at the very beginning of this article, shifts the normative grounds for exceptional experimental interventions from matters of life and death to the realm of vitality of disease (Wahlberg, 2014), that is to say, concerns for improved living conditions for the diseased and a better quality of life.

Third, and closely connected, there is the phenomenon that patients form (sometimes labeled "unholy") alliances with pharmaceutical corporations in their fight against the state's stifling regulations. A small, yet consequential difference here is how the relationships between drug producers, patientsconsumers, and the state are imagined: in most alliances between patients and Pharma, the state is imagined to wrongfully insert itself between active producers (drug companies) and consumers (patients) of pharmaceutical technology. This argumentation operates based on a distinction, conceptual and normative, between production and consumption which is crucial for problematizations of ownership and access rights. By contrast, in those cases of RSCM that I outlined above, the state is allegedly playing another, more forceful role: in its attempt of regulatory pharmaceuticalization (Faulkner, 
2012), the state is charged to expropriate the very bodily stem cells of patients, hence dispossessing them from their autogenous biocapital - the very means of production of regenerative therapies from their own bodily vitality. The flipside of this imagination is that of a harmonious doctor-patient dyad forcefully severed by state intervention.

Taken together, these observations indicate the very post-pharmaceutical horizon articulated in the promissory visions of RSCM. The stakes negotiated in RSCM can be grasped through what Charis Thompson (2018) describes as an aspiration for "better patients", referring to both the "moral and epistemological work patients and their physicians and advocates do which makes the science better and thus makes their treatment work better", and to "the sense of 'being, feeling, or getting better' that we apply to patients who are on the road to recovery or have reduced symptoms and/ or improved quality of life" (Thompson, 2018, p. viii-ix).

Instead of being crude anti-pharmaceutical sentiments, these problematizations of bodies, rights, knowledge, authority, and value point to an incipient regime of health that is in large parts articulated against pharmaceutical notions of health and value. Before exploring these two competing health regimes further, however, we need to develop the conceptual framework first.

\section{Conceptualizing health in the bioeconomy of regenerative medicine}

\section{Health/value}

Health presents a high-ranking normative value in contemporary biopolitical societies - individually, socially, and politically. At the same time, in capitalist societies health is always already embedded in regimes of accumulation to produce value for capital (Sunder Rajan, 2017). If biomedical innovation strategies involve the coproduction of health as both a normative and economic value, a critical concept of health is needed for its analysis. 
Health therefore is conceptualized as a regime, that is, a set of socio-technical relationships that include historically specific and sector-specific forms of knowledge, intervention techniques, and modes of subjectification. At stake analytically is the form of health, that is, its implicit logic, or practical "rationality", constituted through its regime of value. ${ }^{1}$ Hence, a particular form of health cannot be analyzed independently from its particular regime that articulates - in its intertwined semiotic-material sense of "to spell out" and to "cobble together" - the institutional, epistemic, and normative logics and practices that allow health to be produced as a value.

The effort to analyze the nexus between health and value calls for a perspective that considers "value" in different dimensions. To do so, this research draws on scholarship on pharmaceutical values by Joseph Dumit (2012b) and Kaushik Sunder Rajan (2017, p. 16-30), who, both in their distinctive ways, draw upon a Marxian critique of value. Following the approach delineated by Sunder Rajan (2017, p. 17ff), it is key to analyze value in at least three registers: in terms of surplus value for capital; in terms of norms and ethics; and in terms of an antinomy - a self-contradictory relationship between its inherent modalities, such as between use value and market value or between ethical values and capital value. It is this last quality that renders value a deeply political category, for this antinomy can never be fully resolved. Any value regime therefore must be understood as a contingent outcome of power struggles and negotiations that presents only a temporally stable and intrinsically fragile arrangement.

It is through these lenses that I explore how health is articulated and produced (and contested) as a value in pharmaceutical and regenerative health regimes respectively. What is at stake, empirically and conceptually, then, are (1) the specific ways in which actual and projected use values of technology (pharmaceutical drugs and somatic stem cells respectively) and their actual or projected market values co-constitute in their corresponding forms of health (pharmaceutical and regenerative health respectively), and

1The concepts of "regime" and "rationality" draw on governmentality studies (see Dean, 2010). 
(2) how the conflicting tensions between health as a capital value and as an normative value are aligned and stabilized in the respective regimes. These different theoretical concerns and entanglements I seek to capture with the notion of health/value.

\section{Knowledge, value and the bioeconomies of the life science}

Knowledge plays a central role in the bioeconomies of the life sciences, but assumes, as we shall see, different forms and functions in pharmaceutical and regenerative health respectively. Certainly, there is a politics to knowledge to the extent that there are struggles and contestations over which forms of knowledge count as valid in biomedical research and innovation processes. First and foremost, these struggles address tensions between different "levels" of evidence, e.g., between laboratory vs. clinical knowledge, or the role of large-scale clinical trials vs. case study research, but also whether and to which extent experiential/embodied "lay" knowledge form part of biomedical innovation and valuation practices. In the field of RSCM, these politics of knowledge often unfold alongside post-colonial legacies and a geopolitics of knowledge of good Western science vs. bad non-Western science (Bharadwaj, 2018).

Central for a nuanced understanding of health is the relationship between knowledge generation and value generation. The nexus between knowledge and value in RSCM has frequently been discussed with reference to the "global bioeconomy". Bioeconomy is best understood as a dominant policy narrative and a strategic vision of sociotechnical development based on the valorization of renewable biomaterials - from renewable energy sources to human body cells (Lettow, 2015). But the ideas and visions of what the bioeconomy is and how it can unfold and generate value remain largely indefinite and vary between countries and sectors. Hence, regenerative medicine is a central field of articulation and experimentation for the globally emerging bioeconomy (Cooper, 2008; Lettow, 2015), that 
is, a field in which a specific vision of the bioeconomy is articulated and concretized.

Perspectives, however, that posit bioeconomy as "the new thing" and uncritically reproduce policy discourses of its revolutionary innovative character miss significant continuities that exist in the lineages of life, science and economy. With a return to Foucault's work on biopolitics and authors such as Lars Thorup Larsen (2007), Melinda Cooper (2008), or Kaushik Sunder Rajan (2006), I approach the bioeconomy as a field of problematizations and practices in which life (biology) and value (economy) co-constitute mutually and in historically contingent ways. From this angle, both pharmaceutical and regenerative health regimes operate within a certain bioeconomy of the life sciences that need to be explored in their respective specificities.

In this regard, Sabina Leonelli and Kaushik Sunder Rajan have coined the concept of knowledge/value, which they introduce in analogy to Foucault's concept of knowledge/power (Sunder Rajan; Leonelli, 2013). Foucault developed the notion of knowledge/power in order to grasp how the intersecting regimes of knowledge (the human sciences) and forms of power (the disciplinary institution) are veritably coproduced - they cannot be understood in isolation of one another. Similarly, knowledge/value seeks to grasp the constitutive intersecting of knowledge generating practices and value generating practices in today's knowledge-based economy. Whereas Foucault's knowledge/power produces regimes of truth as its effect, knowledge/value produces mobile, convertible and translatable knowledge - knowledge that is valuable in different contexts, such as in the laboratory, the regulatory science office, the shareholder meeting, or the patient clinic. For this study, the notion of knowledge/value sensitizes the analysis to examine the specific coproduction of knowledge and value in the field of regenerative medicine in contrast to other articulations of knowledge/value, such as that at the heart of the pharmaceutical industry.

To make this specific to the field of RSCM, I moreover build on and develop Catherine Waldby's (2002) notion of "biovalue". In her early 
work on stem cell research, Waldby conceives of biovalue as the "yield of vitality produced by the biotechnological reformulation of living processes" (Waldby, 2002, p. 310), that is, as the value-adding surplus of vitality. How this surplus is generated in the field of regenerative stem cell medicine and what specific form it takes needs to be discerned in its own terms.

Finally, the sociotechnical relationships between life, knowledge, and value that underpin different forms of health also shape, and are shaped by, conceptions and valuations of the human body as well as the role of subjects of and in biomedicine. In addition to accounts on patient activism and political patienthood (Epstein, 1996), work on the ethopolitics, somatic selves and biological citizenship (Rose; Novas, 2005; Gibbon; Novas, 2008) provides important impulses. These literatures shed light on processes of subjectification and identity construction in relation to biomedical knowledge and technologies. However, these insights into the neoliberal technologies of individuals and of the self must be supplemented by work that focuses on the exploitation of subjects and their bodies in biomedical labor relationships - such as in the case of experimental subjects or tissue donors (Bharadwaj, 2014; Cooper; Waldby, 2014). The practices that shape biological subjects and selves are therefore analyzed in relation to emerging forms of biocapital sensitive to the double processes of subjectivation and subjugation, a perspective aptly articulated by Sunder Rajan (2006):

On the one hand, what forms of alienation, expropriation, and divesture are necessary for a "culture of biotechnology innovation" to take root? On the other hand, how are individual and collective subjectivities and citizenships both shaped and conscripted by these technologies that concern "life itself"? (Sunder Rajan, 2006, p. 78).

On this basis, we are now prepared to analyze the idiosyncratic regimes of pharmaceutical and regenerative health respectively and contrast them through the prism of their bioeconomies of health, value, knowledge, and subjectivity that underpin them. 


\section{The pharmaceutical form of health}

The birth of pharmaceutical health is conditioned, historically and technologically, by the rise of the chemical and pharmaceutical industries since the late 19th century (Abraham, 2010). Since then, pharmaceuticals have become an integral part of contemporary societies and their material culture (Kleinmann; Petryna, 2006). After having contributed significantly to improving public health worldwide, the pharmaceutical industry committed to promote and enhance health. It presents itself as a research-based industry that focuses on the well-being of patients and public health. At the same time, however, pharmaceutical companies are committed to the capitalist growth and accumulation imperatives, so they must generate profit and grow steadily, which means first and foremost to sell as many drugs as possible. Here, we are confronted with an antinomy of pharmaceutical values: how is it possible that the pharmaceutical enterprise advances technologically and in its mission (making people healthier), and at the same time is able to perpetuate and expand its economic growth model (selling more drugs)? One tentative answer is that Pharma produces health in a special form: as a pill that, if taken regularly, mitigates symptoms. Hence, the preferential commercial interest is in a form of therapy that has a positive effect on the health level of the largest possible population, but only as long as they consume their medication regularly and over a prolonged period "Drugs for Life", as Joseph Dumit (2012a) accurately captures this business model. The motto of a transnational pharmaceutical company involuntarily sums up this logic: "We care for healthier patients" - healthier, yes, but patients, nevertheless. Because when a drug actually heals a disease, the pharmaceutical industry loses a source of profit.

Critics therefore often polemicize that the pharmaceutical industry is only interested in increasing their profits - quite in contrast to their rhetorical call to "enhance health" - and underpin this claim with reference to countless drug scandals, relentless speculation with drug prices, or cases of instrumentalization and exploitation of subjects in clinical trials. In this 
critique of pharmaceutical profit logic, the concept of health is a cynical and ideological one - the declared goal of health maximization is only maintained until it comes into conflict with profit maximization.

\section{Growing health: surpassing barriers to medication}

In order to gain a more complex understanding of pharmaceutical health, I will draw on the work of Joseph Dumit (2012a, 2012b) and explore the pharmaceutical value regime and its rationality. In an effort to move beyond the apparent antinomy between the growing capital value (the economic imperative) and growing health (the moral imperative), Dumit's analysis is inspired by Marx's and Foucault's method of immanent critique. Dumit starts his critique by taking seriously the discourses and practices of the pharmaceutical industry - and its declared goal to, literally, grow health.

The main problem faced by the pharmaceutical industry is, then, what Dumit describes as the problem of "accumulation of drugs in the body", which implies that the biological and normative barriers to medication are overcome in order to increase individual and collective drug intake.

An opportunity for this was created by the rise of an epistemology of risk factors, and, in particular, of molecular biological diagnostics. Through the transformation of clinical diagnostics based on genetics, which is commonly referred to as biomedicalization (Clarke et al., 2003), a new truth discourse of deficient health developed in which everyone is potentially at risk of illness (Lemke, 2011).

This new discourse, which redefined health and illness as a continuum of potentials, formed the epistemic basis for extending drug use from the clinical to the prophylactic phase - that is, from actual patients who subjectively feel a burden of suffering to potential or "becoming" patients. In other words, it is not just about improving the health of actual patients, but also about intervening in the pre-symptomatic phase in order to delay or prevent the possible onset of a disease. This extension of the treatment of diseases to disease potentials, which has also greatly expanded drug markets 
from the clinic into society, has fundamentally changed the "medical gaze" since the birth of the clinic (Foucault, 1963) over the last century.

The problem that follows here, and that presents itself as simultaneously epistemological, normative, and economic, is that of boundary drawing: i.e., the definition of a threshold in the risk continuum, where the onset of prophylactic medication is justified, in order to delay the probable appearance of clinical symptoms or to alleviate the course of a disease.

The strategy of pharmaceutical marketing therefore consisted to a considerable extent in influencing treatment guidelines issued by, for example, medical associations or public health organizations. These define when and under what circumstances a particular drug is indicated in a diagnosis. These treatment guidelines are typically based on expert opinion and clinical trials findings, and are issued by the competent medical specialties. The pharmaceutical industry's strategy is to redefine these thresholds in order to not only broaden the range of possible indications for existing drugs, but also to move forward the point in time when medication is indicated. In order to be able to translate this strategy into the rationality of health care systems - including payers and practitioners - this strategic interest has to be justified rationally and hence be articulated in the register of medical or health economic discourses. It is at this point that clinical trials assume a vital role in these politics of evidence-based norm-setting processes.

\section{Clinical trials and the value of safety}

Clinical trials are paramount in drug research and development (Marks, 1997). They serve different purposes in different contexts: Their primary function is to produce knowledge about the safety and efficacy of medicines, which is a prerequisite for regulatory approval from drug authorities. The pharmaceutical regime relies on a strict separation of research and treatment, which is rationalized in both a scientific and ethical way. Drug development depends scientifically on clinical research on human subjects, whose safety (as research subjects) is the overarching ethical and 
regulatory concerns. The ethical debate about clinical trials is therefore always one of its implementation, which is subject to strict principles and requirements (Wahlberg; McGoey, 2007). Downstream, the drugs available on the market then need to be approved through scientific assessment once again, in order to make their consumption safe for users (patients).

The biopolitics of pharmaceutical safety is thus characterized by a constitutive superimposition of the laboratory and the clinic: it is only when a drug has been tested on humans that it can be used for treatment of humans (Haddad, 2010). While this antinomy between research and treatment is probably characteristic of modern medicine as such, it was institutionalized in a specific way in the US and in Europe in the 1960s, and has become implemented globally from the 1990s onwards (Sunder Rajan, 2017). The ethics of these by now global regimes can be understood primarily as based on an ethics that predominantly values safety, which relies on the constitutive separation of production (clinic as laboratory) and consumption (clinic as market): the protection of subjects in clinical trials, on the one hand, and the protection of the population from dangerous or unchecked medicines, on the other.

The biopolitical paradox of this safety precaution is that a drug becomes all the more "safe" for its use, the greater the number of experiments performed and the larger and more representative the experimental groups involved in it are (Haddad, 2010). Clearly, this normative distinction of research and care has become, time and again, blurred in practice, and was expressively criticized as unethical by patients with terminal illness, such as the HIV/AIDS movement in the 1980s (Epstein, 1996). Nonetheless, this separation remains a constitutive norm of pharmaceutical health regimes.

Since this form of safety relies on large-scale and therefore costly clinical trials, this specific ethics of safety also plays a crucial economic role. On the one hand, lengthy development due to the multi-phase clinical trials process produces significant costs for Pharma. On the other hand, the high organizational and financial costs of this process also benefit large companies that have the necessary specialists and infrastructures to sponsor clinical trials. 
The existing quasi-oligopoly of global Big Pharma is, at least partially, justified in the name of safety. At the same time, the value tensions between safety and profits have led to increased outsourcing of clinical trials to emerging markets in low-income countries (Petryna, 2009). International regimes and their efforts to implement globally universal standards of "good clinical practice" thus serve to protect both subjects and patients worldwide, and sustain the political economy of the Western pharmaceutical industry and its hegemonic value regimes (Sunder Rajan, 2017).

\section{Clinical trials as knowledge/value generator}

Clinical trials, however, play an important role also in the context of the pharmaceutical accumulation strategy of health and value, which is why Dumit (2012b, p. 64-9) describes them as the "machinery" of the pharmaceutical industry. Numerous studies have been commissioned to show that the modification of treatment guidelines is justified by underpinning the advantages of earlier treatment or a higher dose with scientific evidence. Contrary knowledge is not "suppressed" (albeit this happens, too), but simply not produced - and thus does not form part of the pharmaceutical knowledge system. In a context of contemporary societal division of labor, in which most of the clinical knowledge production is carried out by private capitalist corporations, this regime also produces systemic effects: The resulting selectivity of knowledge about indication, medication, dosage, etc. is further propelled by a strategic "will to ignorance" (McGoey, 2012), such as when a drug should be discontinued or its dose reduced. In this context, clinical trials not only serve the function of a sophisticated marketing tool, but also constitute the "machine" for the production of pharmaceutical knowledge/value, which is central to the understanding of health in the context of pharmaceutical biopolitics.

For Dumit, the quest for preventive health mediated through an epistemology of risk factors and clinical trials can be understood as the creation of surplus health as the central pharmaceutical rationality for growing 
value. Paralleling Marx's analysis of concrete and abstract labor in the creation of surplus value, surplus health presents an abstract category of Health (with capital H) that, while always the product of concrete human health, does not quite correspond to subjective feelings of embodied healthiness. The steady expansion of consumption and the steady suppression of natural and normative barriers to medication must therefore be understood as the production of "surplus health", which forms the basis of pharmaceutical valorization (Dumit, 2012b).

Taken together, the contours of the pharmaceutical regime of health become evident, which persist not in the elimination of illness, but in the management of its symptoms that is preferably accomplished through prophylactic and chronic medication. It also relies on the qualitative and quantitative extension of medication, rationalized by knowledge produced by clinical trials and stabilized in treatment guidelines. The ethics of the pharmaceutical regime is an ethics of safety, based on an institutional separation between production and consumption of standardized products sold in regulated markets.

\section{Post-pharmaceutical regenerative health}

With pharmaceutical health as a contrast foil, I now want to examine the logics of regenerative health in stem cell medicine. If the guiding vision of stem cell medicine is regeneration - that is, actual healing - then the question arises which valorisation logic of knowledge and bodies underpins the logic of regenerative health, or: What is the accumulation of postpharmaceutical health/value based on?

\section{Accumulating biovalue}

For at least the last twenty years, RSCM has spawned a new truth discourse of health and disease that has shaken certain basic assumptions of conventional biomedicine. Human cell technologies have allowed human cells to be isolated and propagated in the laboratory. In conjuncture with 
a variety of legal technologies that helped to disentangle human cells from the subjects' body proper and render them independently "propriable" (Cooper; Waldby, 2014), these developments have paved the way to make living cells viable for circulation (Lettow, 2015).

In the first years of adult stem cell therapies, RSCM mainly capitalized on experimental and ad-hoc treatments based on patients' own body stem cells. In such procedures, patients are treated with their own cells extracted only shortly - typically only a few hours or days - before they are reinserted to the diseased location. The customers of RSCM offerings, hence, had been predominantly actual patients with a high level of suffering or life-threatening illnesses with no prospect of effective therapies from the established conventional medical spectrum. In recent years, however, the field has undergone significant changes. A different model geared towards a long-term valorization of stem cell therapies has gathered momentum that complements the model of immediate treatment offerings. In this emerging model, extraction and long-term storage of a patient's stem cells is key both in clinical and commercial regard. Bio-banks were founded as sites where cells and tissue samples are stored under appropriate technical and regulatory conditions designed to maintain the quality, genetic stability, and biological potency of human cells ex vivo (Hauskeller; Beltrame, 2016). Consequently, no longer the clinical treatment center, but rather the biobank became the institutional nodal point, assuming a crucial role for the long-term accumulation of value.

Clinically, there is the assumption that a greater quantity of stem cells is available from a young and healthy individual, compared to an older individual afflicted by disease, but also that the quality of the cells understood in terms of their potency and regenerative capacities - is better. It follows from a biomedical point of view that it makes sense to remove stem cells as early as possible and store them, so that they can be used as a regenerative resource in the case of disease.

This knowledge has direct bearing on bioeconomic value accumulation: The strategic-commercial goal here is to make as many people as possible 
clients of stem cell banks and to manage the largest possible quantity of their stem cells for as long as possible - the extraction and extracorporeal storage of vitality. A process similar to that of the shift, in pharmaceutical logics, from actual disease to disease potentials can be observed here: the systematic expansion from actual to potential future patients. Individuals are interpellated simultaneously as potential patients, as proactive managers of their medical future, and as owners of their stem cells to store them (and those of their relatives, or, at company level, their employees) in stem cell banks, so they can resort to it in case of illness. Again, the epistemology of risk factors comes into play, but not to justify a pre-symptomatic treatment, but to rationalize the extraction of body stem cells as early as possible and in the largest possible quantities.

In this context, adult stem cell companies have begun to position themselves less as research-based companies or clinical treatment centers narrowly understood, but as biomedical service providers and "brokers" - intermediaries that not only organize clinics, clients, and their cells, but also mediate between biomedical present and future.

\section{Generating speculative surplus vitality}

If the pharmaceutical valorization of health consists in the production of abstract "surplus health" based on symptomatic therapy and increased medication, how can one understand the bioeconomy of regenerative health, whose post-pharmaceutical vision is founded on the promise of effective treatment and recovery?

So far we have seen that at its core is the collection and storage of stem cells as biocapital - a resource to re-generate vitality. Moreover, the following logic applies: The "younger" the body of which stem cells are extracted and the more of them are stored, the higher their potential use value. Here, we find a double speculative logic of biovalue - not only subjective and personal, but also technoscientific. On the one hand, this bioeconomy of RSCM articulates a logic of anticipatory self-care, as it 
interpellates subjects as prudent managers of their vitality by preparing themselves for a possible emergency in the future. On the other hand, in view of the present state of the actual possibilities of RSCM, which stands in stark contrast to the enormous biomedical promise of RSCM in the future, one speculates on the latter: on great advances of treatment options in the future, which can then be translated into surplus vitality conserved in the form of one's own stem cell bank.

This collapsing boundary between production and consumption is also reflected in the register of ethical subjectification, as consumers of their own stem cells become (co)producers of biovalue. Against this background, the subject of regenerative health fashions itself as a rational subject of precaution and a subject of speculative investments in future biocapital. In doing so, clients not only invest in their individual biomedical future, but also in the technoscientific development of the field of regenerative medicine, the advancement of its clinical application, and of knowledge infrastructures.

Through the lenses of Catherine Waldby's (2002, p. 310) notion of biovalue as the value-adding surplus of vitality yielded by the "biotechnological reformulation of living processes", we can now discern the form of biovalue encapsulated in the making of post-pharmaceutical health in RSCM. This regenerative biovalue is produced in the accumulation of "surplus vitality", whereby its logic lies in the extraction, storage, and preservation of vitality in the context of a speculative bioeconomy of regenerative medicine. Somewhat akin to Dumit's notion of "Health", vitality here must not be understood as a concrete embodied state of well-being, strength, and healthiness experienced by a subject, but rather as a material abstraction in the form of extracted stem cells. 


\section{Discussion: Towards an incipient future of post- pharmaceutical health?}

In RSCM an incipient form of regenerative health can be identified that significantly diverges from the dominant pharmaceutical regime in many respects.

The health regimes of the 20th century, which were based in large parts not merely on pharmaceutical drug products, but also on specific pharmaceutical logics of producing and valuing health - economically, politically, ethically -, are problematized and challenged by the emergent regime of RSCM. Yet, far from simply being "anti-pharmaceutical", it would be more precise to suggest that RSCM articulates a form of post-pharmaceutical health that does not entirely dismiss the logics of pharmaceutical regimes of health and value, but significantly reconfigures them.

When compared and contrasted, pharmaceutical and regenerative health hence reveal crucial differences in the ways biomedical research, treatment, and innovation are articulated into regimes of value. First, in a growing domain of somatic stem cell therapy, the concept of drug development is being questioned in favor of an experimental medical innovation process, shifting the place of biomedical innovation from the bounded space of the pharmaceutical pipeline into a more diffuse field between clinic and market. At its present state of development, we find a rather diminished role for controlled clinical trials as principal technology for knowledge/value - knowledge that produces surplus for capital. Among other things, this is probably due to the fact that in efforts to accumulate surplus, regenerative health shifts the focus from pre-symptomatic medication (justified by evidence from clinical trials) to pre-onset extraction of stem cells. The fact that stem cell applications are commodified not so much as standardized "off-the-shelf" products (such as drugs), but rather as procedures - operations performed by clinicians -, in a global biomedical service economy that are dependent on a patient's own bodily materials, gives shape to a different biopolitics of economic and ethical valuation 
of vitality: sociotechnical practices of appropriation, expropriation, and valorization of bodies and of health and disease on the one hand; ethical valuations and rights to treatment, ownership, and access, on the other.

How do these observations speak to our understandings of health in the emerging global bioeconomy? The assertion that bioeconomy does not only present new biotechnological markets but constitutes a new field of (re)productive forces in contemporary techno-scientific capitalism is key: the struggles fought over the proper regulatory frameworks address the entire web of hierarchically arranged values and power relations between biomedicine, industry, and the state, which are symbolically and materially inscribed into the bodies of patients. Hence, RSCM does not only go beyond Pharma by providing a different - and self-declaredly better - means of providing health in the sense of an advanced biomedical technology, but challenges and alters the very ways in which health and disease are conceptualized, valued, and acted upon, and how biomedical innovation processes are imagined and pursued.

What are, then, the broader empirical and political prospects of this emergent form of post-pharmaceutical health? To begin with, as a truly global phenomenon the spread of clinical and commercial forms of patientbased stem cell therapies is rapidly growing, with no signs of stopping. Largely, this field is driven by experimental treatment applications that are difficult to regulate (Sipp et al., 2017). Thousands of patients who have the necessary purchase power to buy such expensive treatments on a global marketplace "just do it", and can do it simply because of the sociotechnical relations that underpin the global bioeconomy of RSCM, such as the easy technological basis for autologous therapies, the regulatory discrepancies between different biomedical jurisdictions, social media propagation, cheap flights and huge health care asymmetries on a global scale, etc. The direct treatment approach is increasingly complemented by a growing industry of mostly private stem cell banks that provide broader sociotechnical and institutional infrastructures. Yet, at present, it is hard to anticipate whether and to what extent the pharmaceutical regime will 
actually lose dominance. Current developments rather point to a trend of pluralization and superimposition of the two health regimes on a global scale (Rosemann; Chaisinthrop, 2016). Moreover, an increasing number of governments and public institutions are supporting precisely this emerging field of RSCM because of its huge innovation potential - often in open conflict with dominant biomedical communities, other state apparatuses, and biocapital factions (Haddad, 2016).

Finally, what, if at all, does the notion of post-pharmaceutical health help us to perceive and analyze beyond the realm of RSCM? We have introduced post-pharmaceutical health as a sensitizing concept to explore to date dispersed developments that challenge the pharmaceutical rationality of drug research, commerce and treatment. These practical and politicized forms of critique target the global hegemony of vested interests of pharmaceutical corporations perpetuated by its particular regulatory frameworks, patent regimes, and innovation models. However, as the analysis of regenerative health makes clear, one should be circumspect of normative evaluations of post-pharmaceutical health, as they reproduce different yet similar accumulation logics through exploitation of subjects and expropriation of bodies. Future sociological research hence might examine emergent forms of post-pharmaceutical health in different fields and spaces, and map out and critically analyze the struggles, conflicts, and processes over, within and at the margins of pharmaceutical rationalities and their corresponding regimes of value. 


\section{Acknowledgements}

An earlier draft of this paper was presented at the Annual Meeting of the Society for the Social Studies of Science (4S) 2017, Boston. I would like to thank Renan Leonel for encouragement and patience, as well as Julia Sachseder and the two anonymous reviewers for their comments and suggestions that have helped to substantially improve this paper. All remaining errors of fact or judgment are clearly mine.

Christian Haddad is a research fellow at the Austrian Institute for International Affairs and a lecturer at the University of Vienna (Dept. of Political Science; Dept. of Science \& Technology Studies).

Đchristian.haddad@oiip.ac.at 


\section{References}

1. ABBOTT, Alison. Stem-cell ruling riles researchers. Nature, v. 495, n. 7442, p. 418-19, 2013.

2. ABRAHAM, John. Pharmaceuticalization of society in context: theoretical, empirical and health dimensions. Sociology, v. 44, p. 603-22, 2010.

3. ANNAS, George J. Cancer and the constitution - Choice at life's end. New England Journal of Medicine, v. 357, p. 408-13, 2007.

4. BERRY, Carol. The dividing line between the role of the FDA and the practice of medicine: a historical review and current analysis. Digital Access to Scholarship at Harvard, 1997. Available at: http://nrs.harvard.edu/urn-3:HUL. InstRepos:8846812.

5. BHARADWAJ, Aditya. Experimental subjectification: the pursuit of human embryonic stem cells in India. Ethnos, v. 79, n. 1, p. 84-107, 2014.

6. BHARADWAJ, Aditya. Stem cell intersections: perspectives and experiences. In: BHARADWAJ, A. (Ed.). Global perspectives on stem cell technologies. Cham: Palgrave MacMillan, 2018, p. 1-24.

7. BLASIMME, Alessandro. Translating stem cells to the clinic: scientific societies and the making of regenerative medicine. Quaderni, v. 2, p. 29-44, 2013.

8. BIEHL, Joao. Pharmaceuticalization: AIDS treatment and global health politics. Anthropological Quarterly, v. 80, p. 1083-126, 2007.

9. BROWN, Nik; KRAFT, Alison; MARTIN, Paul. The promissory pasts of blood stem cells. BioSocieties, v. 1, n. 3, p. 329-48, 2006.

10. CLARKE, Adele et al. Biomedicalization: technoscientific transformations of health, illness, and U.S. biomedicine. American Sociological Review, v. 68, n. 2, p. 161-94, 2003.

11. COOPER, Melinda. Life as surplus. Biotechnology and capitalism in the neoliberal era. Seattle: University of Washington Press, 2008.

12. COOPER, Melinda; WALDBY, Catherine. Clinical labor: tissue donors and research subjects in the global bioeconomy. Durham: Duke University Press, 2014.

13. CYRANOSKI, David. US drug regulator audits Texas stem-cell company. Nature News Blog, 2012. Available at: http://blogs.nature.com/news/2012/06/ fda-hammers-texan-stem-cell-company.html.

14. DEAN, Mitchell. Governmentality. Power and rule in modern society. London: Sage, 2010.

15. DUMIT, Joseph. Drugs for life: how pharmaceutical companies define our health. Durham: Duke University Press, 2012a

16. DUMIT, Joseph. Prescription maximization and the accumulation of surplus health in the pharmaceutical industry: the Biomarx experiment. In: SUNDER 
RAJAN, Kaushik (Ed.). Lively capital: biotechnologies, ethics, and governance in global markets. Durham: Duke University Press, 2012 b. p. 45-92.

17. EPSTEIN, Steven. Impure science: AIDS, activism, and the politics of knowledge. Berkeley: University of California Press, 1996.

18. FAULKNER, Alex. Tissue engineered technologies: regulatory pharmaceuticalization in the European Union. Innovation: The European Journal of Social Science Research, v. 25, p. 389-408, 2012.

19. FOUCAULT, Michel. Naissance de la clinique. Une archéologie du regard médical. Paris: Presses universitaires de France, 1963.

20. GIBBONS, Sarah; NOVAS, Carlos. Biosocialities, genetics and the social sciences. Making biologies and identities. London: Routledge, 2008.

21. GOTTWEIS, Herbert; SALTER, Brian; WALDBY, Catherine. The global politics of human embryonic stem cell science. London: Palgrave Macmillan, 2009.

22. HADDAD, Christian. Zwischen Labor und Gesellschaft. Zur Biopolitik klinischer Forschung am Menschen. Frankfurt: Peter Lang, 2010.

23. HADDAD, Christian. Services in the self: embodied labor and the global bioeconomy. Life Sciences, Society and Policy, v. 11, n. 9, p. 1-11, 2015.

24. HADDAD, Christian. The biopolitics of innovation: (re-)articulating visions and values of research, regulation and experimentation in the making of regenerative stem cell medicine. 2016. Dissertation (Doctor of Philosophy) Faculty for Social Sciences, University of Vienna, Austria.

25. HADDAD, Christian; CHEN, Haidan; GOTTWEIS, Herbert. Unruly objects: novel innovation paths and their regulatory challenge. In: WEBSTER, Andrew (Ed.). The global dynamics of regenerative medicine. Houndsmill: Palgrave MacMillan, 2013, p. 88-117.

26. HAUSKELLER, Christine, BELTRAME, Lorenzo. The hybrid bioeconomy of umbilical cord blood banking: re-examining the narrative of opposition between public and private services. BioSocieties, v. 11, n. 4, p. 415-34, 2016.

27. ISSCR - International Society of Stem Cell Research. Guidelines for the clinical translation of stem cells. Skokie: ISSCR, 2008. Available at: http://www. isscr.org/home/publications/ClinTransGuide.

28. KLEINMANN, Arthur; PETRYNA, Adriana. The pharmaceutical nexus. In: PETRYNA, Adriana; LAKOFF, Andrew; KLEINMANN, Arthur (Eds.). Global pharmaceuticals. Ethics, markets, practices. Durham: Duke University Press, 2006, p. 1-32.

29. LARSEN, Lars. Speaking truth to biopower: on the genealogy of bioeconomy. Distinktion: Scandinavian Journal of Social Theory, v. 8, p. 9-24, 2007.

30. LEMKE, Thomas. Biopolitics. An advanced introduction. New York: New York University Press, 2011.

31. LETTOW, Susanne. Biokapitalismus und Inwertsetzung der Körper. PROKLA Zeitschrift für kritische Sozialwissenschaft, v. 178, n. 1, p. 33-49, 2015. 
32. MARKS, Harry. The progress of experiment. Science and therapeutic reform in the United States, 1900-1990. Cambridge: Cambridge University Press, 1997.

33. McGOEY, Linsey. Strategic unknowns: towards a sociology of ignorance. Economy \& Society, v. 41, n. 1, p. 1-16, 2012.

34. MORRISON, Michael. Promissory futures and possible pasts: the dynamics of contemporary expectations in regenerative medicine. BioSocieties, v. 7, p. 3-22, 2012.

35. PETRYNA, Adriana. When experiments travel. Clinical trials and the global search for human subjects. Princeton: Princeton University Press, 2009.

36. PR NEWSWIRE. Colorado medical clinic welcomes opportunity to fight FDA in court. PR Newswire, 9 Aug. 2010. Available at: https://www.prnewswire.com/ news-releases/colorado-medical-clinic-welcomes-opportunity-to-fight-fda-incourt-100247969.html.

37. ROSE, Nikolas; NOVAS, Carlos. Biological citizenship. In: ONG, Andrew; COLLIER, Stephen (Eds.). Global assemblages: technology, politics, and ethics as anthropological problems. Malden: Blackwell Publishing, 2005, p. 439-63.

38. ROSEMANN, Achim et al. Global regulatory developments for clinical stem cell research: diversification and challenges to collaborations. Regenerative medicine, v. 11, p. 647-57, 2016.

39. ROSEMANN, Achim; CHAISINTHROP, Nattaka. The pluralization of the international: resistance and alter-standardization in regenerative stem cell medicine. Social Studies of Science, v. 46, n. 1, p. 112-39, 2016.

40. SALTER, Brian; ZHOU, Yinhua; DATTA, Saheli. Hegemony in the marketplace of biomedical innovation: consumer demand and stem cell science. Social Science \& Medicine, v. 131, p. 156-63, 2015.

41. SIPP, Douglas et al. Marketing of unproven stem cell-based interventions: a call to action. Science translational medicine, v. 9, n. 397, p. eaag0426, 2017.

42. SUNDER RAJAN, Kaushik. Biocapital: the constitution of postgenomic life. Durham: Duke University Press, 2006.

43. SUNDER RAJAN, Kaushik. Pharmocracy: value, politics, and knowledge in global biomedicine. Durham: Duke University Press, 2017.

44. SUNDER RAJAN, Kaushik; LEONELLI, Sabina. Introduction: biomedical transactions, postgenomics, and knowledge/value. Public Culture, v. 25, p. 463-75, 2013.

45. TERSAL. Stop FDA shutting down adult stem cell research. Care2, 2012. Available at: http://www.thepetitionsite.com/de/1/PetitionforAdultStemCells/.

46. THOMPSON, Charis. Foreword. Good science, better patients. In: BHARADWAJ, Aditya (Ed.) Global perspectives on stem cell technologies. Chams: Palgrave MacMillan, 2018, p. v-X.

47. WAHLBERG, Ayo. Knowledge of living. Somatosphere, v. 10, 2014. Available at: http://somatosphere.net/?p=9476. 
48. WAHLBERG, Ayo; McGOEY, Linsey. An elusive evidence base: the construction and governance of randomized controlled trials. BioSocieties, v. 2, p. 1-10, 2007. 49. WALDBY, Catherine. Stem cells, tissue cultures and the production of biovalue. Health, v. 6, n. 3, p. 305-23, 2002.

50. WEBSTER, Andrew. The global dynamics of regenerative medicine: a social science critique. London: Palgrave Macmillan, 2013.

51. WILSON, James. A history lesson for stem cells. Science, v. 324, p. 727-8, 2009.

52. WOOLHOUSE, Mark; FARRAR, Jeremy. Policy: an intergovernmental panel on antimicrobial resistance. Nature, v. 509, n. 7502, p. 555, 2014. 